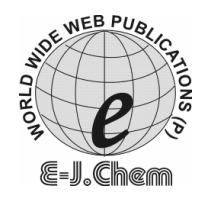

http://www.e-journals.net
ISSN: 0973-4945; CODEN ECJHAO

E-Journal of Chemistry

2009, 6(2), 569-576

\title{
Crystalline and Molecular Structure of Hydrated 2,6-Xylidinium Tetrachlorozincate(II)
}

\author{
W. SMIRANI* and M. RZAIGUI \\ Laboratoire de chimie des Matériaux, \\ Faculté des Sciences de Bizerte, 7021 Zarzouna, Tunisie. \\ wajda_sta@yahoo.fr
}

Received 22 March 2008; Accepted 1 May 2008

\begin{abstract}
A new zinc complex compound of formula [2,6- $\left(\mathrm{CH}_{3}\right)_{2}$ $\left.\mathrm{C}_{6} \mathrm{H}_{3} \mathrm{NH}_{3}\right]_{2} \mathrm{ZnCl}_{4}$. $2 \mathrm{H}_{2} \mathrm{O}$ has been prepared and characterized by $\mathrm{X}$-ray crystallography, thermal analysis and IR spectroscopy. The complex crystallizes in the monoclinic space group $\mathrm{P} 2{ }_{1} / \mathrm{a}$ with a minimal tetrahedral distortion of the $\mathrm{ZnCl}_{4}{ }^{2-}$ ion, $\mathrm{a}=7.448(1) \AA, \mathrm{b}=38.486(3) \AA, \mathrm{c}=8.298(1) \AA, \beta=112.52(1)^{\circ}$, $\mathrm{V}=2197.4(4) \AA^{3}$ and $\mathrm{Z}=4$. The crystal structure was solved and refined to $\mathrm{R}=$ 0.047 with 3270 independent reflections. It can be described by inorganic layers of $\left[\mathrm{ZnCl}_{4} \cdot\left(\mathrm{H}_{2} \mathrm{O}\right)_{2}\right]^{2-}$ parallel to $(010)$ plane, between which the 2,6-xylidinium cations are located. The grouping is maintained by different types of interactions (electrostatic, H-bonds, Van der Walls and $\pi-\pi$ stacking). A characterization of this compound by thermal analysis and IR spectroscopy are also reported.
\end{abstract}

Keywords: Zinc(II) complex, X-ray crystal structure, H-Bond, Thermal behaviour, IR spectroscopy.

\section{Introduction}

Hybrid materials with organic and inorganic components are an attractive field of research due to their ability to combine the properties of organic and inorganic compounds within one single molecular scale, so as to exhibit some interesting crystal structure and some special properties in several areas, such as nonlinear optical (NLO), magnetism, luminescence, etc $^{1-8}$. It is therefore vital to design and synthesize novel salts with inorganic anions and organic cations to explore their various properties. A recent advance in this system is to design the coordination frameworks of metal halides by the incorporation of various organic structuredirecting agents and generating new supramolecular entities ${ }^{9-13}$. In the present investigation we report the synthesis and crystal structure of a new organic-inorganic hybrid zinc complex, $\left[2,6-\left(\mathrm{CH}_{3}\right)_{2}-\mathrm{C}_{6} \mathrm{H}_{3} \mathrm{NH}_{3}\right]_{2} \mathrm{ZnCl}_{4} \cdot 2 \mathrm{H}_{2} \mathrm{O}$ (Figure 1). Its characterization by thermal analysis and IR spectroscopy are also reported. 


\section{Experimental}

\section{Synthesis}

Crystals of $\mathrm{Zn}$ (II) complex with 2,6-xylidine, $\left(\mathrm{C}_{8} \mathrm{H}_{12} \mathrm{~N}\right)_{2} \mathrm{ZnCl}_{4} \cdot 2 \mathrm{H}_{2} \mathrm{O}$, were prepared by slow evaporation of an aqueous solution of 2,6-xylidine, $\mathrm{HCl}$ and $\mathrm{ZnCl}_{2}$ (2:2:1) molar. Crystals are stable for a long-time in normal conditions of temperature and humidity. The chemical formula was determined when resolving the crystal structure by X-ray diffraction spectroscopy.

\section{Investigation techniques}

$X$ - ray diffraction

A single crystal of the complex was mounted on a MACH 3 Enraf Nonius diffractometer operating at $296 \mathrm{~K}$ with a monochromated Mo radiation source $(\lambda=0.7107 \AA)$. The structure was solved by direct methods using the SIR $92^{14}$ program and refined by full matrix leastsquares techniques based on $F$ using teXsan ${ }^{15}$. The hydrogen atoms were not refined, and all non-hydrogen atoms were refined anisotropically. Further details of structural analyses are summarized in Table 1.

Table 1. Crystal and experimental data.

\begin{tabular}{ll}
\hline Empirical formula & $\mathrm{C}_{16} \mathrm{H}_{28} \mathrm{Cl}_{4} \mathrm{~N}_{2} \mathrm{O}_{2} \mathrm{Zn}$ \\
\hline Formula weight & 487.60 \\
$T(\mathrm{~K})$ & 293 \\
Wavelength $(\AA)$ & 0.71069 \\
Crystal system & Monoclinic \\
Space group & $P 2_{1} / a$ \\
$a(\AA)$ & $7.448(1)$ \\
$b(\AA)$ & $38.486(3)$ \\
$c(\AA)$ & $8.298(1)$ \\
$\beta\left({ }^{\circ}\right)$ & $112.52(1)$ \\
$V\left(\AA^{3}\right)$ & $2197.4(4)$ \\
$Z$ & 4 \\
$D$ calc $\left(\mathrm{g} \mathrm{cm}^{-3}\right)$ & 1.474 \\
$\mu($ MoK $\alpha)\left(\mathrm{mm}^{-1}\right)$ & 1.616 \\
$F(000)$ & 1008 \\
Reflections collected/unique, $R$ int & $8487 / 5392,(0.021)$ \\
Observed data $(I>3 \sigma(I))$ & 3270 \\
No. of variables & 226 \\
Goodness-of-fit & 1.58 \\
$R$ & 0.047 \\
$R w$ & 0.058 \\
\hline
\end{tabular}

The final atomic coordinates of the non-hydrogen atoms and their equivalent isotropic displacement parameters, Beq, are given in Table 2. The drawings were made with Diamond $^{16}$. Crystallographic data (CIF) for the structure reported in this paper have been deposited in the Cambridge Crystallographic Data centre as supplementary materials No 682367. Copies of the data can be obtained, free of charge, on application to the CCDC, 12 Union Road, Cambridge CB12EZ, UK 
Table 2. Final atomic coordinates and $\mathrm{B}_{\mathrm{eq}}\left(\AA^{2}\right)$ of the non-hydrogen atoms of $\left[2,6-\left(\mathrm{CH}_{3}\right)_{2}\right.$ $\left.\mathrm{C}_{6} \mathrm{H}_{3} \mathrm{NH}_{3}\right]_{2} \mathrm{ZnCl}_{4} \cdot 2 \mathrm{H}_{2} \mathrm{O}$.

\begin{tabular}{lllll}
\hline Atoms & \multicolumn{1}{c}{$\mathrm{x}(\sigma)$} & \multicolumn{1}{c}{$\mathrm{y}(\sigma)$} & \multicolumn{1}{c}{$\mathrm{z}(\sigma)$} & $\mathrm{B}_{\mathrm{eq}}$ \\
\hline $\mathrm{Zn}(1)$ & $0.17423(6)$ & $0.127982(10)$ & $0.07366(5)$ & $2.753(9)$ \\
$\mathrm{Cl}(1)$ & $0.2910(2)$ & $0.16848(3)$ & $-0.05600(13)$ & $4.20(2)$ \\
$\mathrm{Cl}(2)$ & $0.1546(2)$ & $0.07808(2)$ & $-0.07917(13)$ & $3.78(2)$ \\
$\mathrm{Cl}(3)$ & $0.3811(2)$ & $0.12374(3)$ & $0.35975(12)$ & $3.91(2)$ \\
$\mathrm{Cl}(4)$ & $-0.1185(2)$ & $0.14056(3)$ & $0.0808(2)$ & $4.63(3)$ \\
$\mathrm{O}(1)$ & $0.5072(5)$ & $0.36774(9)$ & $0.5345(4)$ & $5.63(8)$ \\
$\mathrm{O}(2)$ & $0.5303(5)$ & $0.09524(9)$ & $0.8188(4)$ & $6.39(10)$ \\
$\mathrm{N}(1)$ & $0.7197(5)$ & $0.06959(8)$ & $0.6202(4)$ & $3.26(7)$ \\
$\mathrm{N}(2)$ & $0.7039(5)$ & $0.17973(8)$ & $0.3284(4)$ & $3.57(7)$ \\
$\mathrm{C}(1)$ & $0.7347(5)$ & $0.03355(9)$ & $0.5698(4)$ & $2.73(7)$ \\
$\mathrm{C}(2)$ & $0.7354(5)$ & $0.02733(10)$ & $0.4045(5)$ & $3.13(8)$ \\
$\mathrm{C}(3)$ & $0.7548(6)$ & $-0.00735(11)$ & $0.3639(5)$ & $3.70(9)$ \\
$\mathrm{C}(4)$ & $0.7743(6)$ & $-0.03369(10)$ & $0.4815(6)$ & $3.85(9)$ \\
$\mathrm{C}(5)$ & $0.7732(6)$ & $-0.02615(10)$ & $0.6431(5)$ & $3.55(9)$ \\
$\mathrm{C}(6)$ & $0.7535(5)$ & $0.00752(9)$ & $0.6919(4)$ & $2.85(8)$ \\
$\mathrm{C}(7)$ & $0.7141(7)$ & $0.05568(12)$ & $0.2759(5)$ & $4.64(11)$ \\
$\mathrm{C}(8)$ & $0.7494(6)$ & $0.01519(10)$ & $0.8691(5)$ & $3.50(9)$ \\
$\mathrm{C}(9)$ & $0.7100(5)$ & $0.21607(9)$ & $0.3894(5)$ & $2.75(7)$ \\
$\mathrm{C}(10)$ & $0.7020(5)$ & $0.24251(10)$ & $0.2731(5)$ & $3.08(8)$ \\
$\mathrm{C}(11)$ & $0.7094(6)$ & $0.27648(10)$ & $0.3350(6)$ & $3.95(10)$ \\
$\mathrm{C}(12)$ & $0.7214(6)$ & $0.28286(11)$ & $0.5021(6)$ & $4.50(11)$ \\
$\mathrm{C}(13)$ & $0.7268(6)$ & $0.25569(12)$ & $0.6103(5)$ & $4.19(10)$ \\
$\mathrm{C}(14)$ & $0.7224(5)$ & $0.22149(10)$ & $0.5586(5)$ & $3.23(8)$ \\
$\mathrm{C}(15)$ & $0.6891(6)$ & $0.23591(11)$ & $0.0905(5)$ & $3.91(9)$ \\
$\mathrm{C}(16)$ & $0.7296(7)$ & $0.19200(13)$ & $0.6798(5)$ & $4.84(11)$ \\
\hline
\end{tabular}

Estimated standard deviations are given in parentheses.

\section{IR Spectroscopy}

IR spectrum was recorded in the range 4000-400 $\mathrm{cm}^{-1}$ with a "Perkin-Elmer Spectrum 1000" spectrophotometer using a sample dispersed in spectroscopically pure $\mathrm{KBr}$ pellet.

\section{Thermal analysis}

Thermal analysis was performed using the "multimodule 92 Setaram analyzer" operating from room temperature up to $723 \mathrm{~K}$ at an average heating rate of $5 \mathrm{~K} \cdot \mathrm{min}^{-1}$.

\section{Results and Discussion}

Structure description

The main geometrical features of different entities are reported in Table 3. Figure 1 shows the ORTEP ${ }^{17}$ plot of the asymmetric unit of $\left[2,6-\left(\mathrm{CH}_{3}\right)_{2}-\mathrm{C}_{6} \mathrm{H}_{3} \mathrm{NH}_{3}\right]_{2} \mathrm{ZnCl}_{4} \cdot 2 \mathrm{H}_{2} \mathrm{O}$, containing two 2,6-xylidinium cations, two water molecules and one tetrachlorozincate anion. A view of the structure projected along the axis is given in Figure 2. This projection shows that the most striking feature of this architecture is the assembly of the $\left(\mathrm{ZnCl}_{4}\right)^{2-}$ anions and the water molecules into two-dimensional network, parallel to ac planes at $y=(2 n+1) / 8$, with the hydrogen-bonded cations protruding on both sides of the network. Adjacent twodimensional networks interpenetrate each other and pack through $\pi$ - $\pi$ stacking interactions 
between the xylidinium cations. There are two different $\pi$ - $\pi$ interactions between identical antiparallel cations, with face to face distances of 3.649 and $3.735 \AA$, less than 3.8 , maximum value accepeted for $\pi$ - $\pi$ interactions ${ }^{18}$. As shown in Figure 3 , in the crystal structure of the title complex, the inorganic and organic species interact by mean of a network of four $\mathrm{O}-\mathrm{H} . . . \mathrm{Cl}$, two $\mathrm{N}-\mathrm{H} \ldots \mathrm{O}$ and four $\mathrm{N}-\mathrm{H}$...Cl hydrogen bonds (Table 4), giving rise to a porous layer. It is notable that the distances $\mathrm{H}$...Cl varies between 1.83 and $2.58 \AA$. These values are smaller than the sum of the radii of Van Der Waals of the chlorine and hydrogen atoms $\left(\mathrm{r}_{\mathrm{Cl}}+\mathrm{r}_{\mathrm{H}} \leq 2.81 \AA\right)$. Consequently, these values correspond well to strong bonds. All these hydrogen bonds, as well as coulombic attractions, Van der Walls forces and $\pi$ - $\pi$ interactions, act as an important and predictable structural organizing tool and increase so the structure stability of the title hybrid material.

Table 3. Selected bond lengths $(\AA)$ and angles $\left(^{\circ}\right)$ in $\left[2,6-\left(\mathrm{CH}_{3}\right)_{2}-\mathrm{C}_{6} \mathrm{H}_{3} \mathrm{NH}_{3}\right]_{2} \mathrm{ZnCl}_{4} \cdot 2 \mathrm{H}_{2} \mathrm{O}$.

The $\mathrm{ZnCl}_{4}$ tetrahedron

\begin{tabular}{cccc}
\hline $\mathrm{Zn}-\mathrm{Cl} 1$ & $2.250(1)$ & $\mathrm{Cl}-\mathrm{Zn} 1-\mathrm{Cl} 1$ & $114.74(6)$ \\
$\mathrm{Zn}-\mathrm{Cl} 2$ & $2.2751(13)$ & $\mathrm{Cl} 1-\mathrm{Zn} 1-\mathrm{Cl} 3$ & $105.17(6)$ \\
$\mathrm{Zn}-\mathrm{Cl} 3$ & $2.2881(13)$ & $\mathrm{Cl} 1-\mathrm{Zn} 1-\mathrm{Cl} 3$ & $108.40(6)$ \\
$\mathrm{Zn}-\mathrm{Cl} 4$ & $2.256(1)$ & $\mathrm{Cl}-\mathrm{Zn} 1-\mathrm{Cl} 2$ & $109.84(6)$ \\
$\mathrm{Cl} 3-\mathrm{Zn} 1-\mathrm{Cl} 2$ & $113.09(6)$ & $\mathrm{Cl} 1-\mathrm{Zn} 1-\mathrm{Cl} 2$ & $105.80(5)$ \\
\hline
\end{tabular}

The 2,6-xylidinium groups

2,6- $\left(\mathrm{CH}_{3}\right)_{2}-\mathrm{C}_{6} \mathrm{H}_{3} \mathrm{~N}(\mathrm{l}) \mathrm{H}_{3}$

\begin{tabular}{cccccc}
\hline $\mathrm{N} 1-\mathrm{C} 1$ & $1.465(6)$ & $\mathrm{C} 1-\mathrm{C} 2$ & $1.394(6)$ & $\mathrm{C} 1-\mathrm{C} 6$ & $1.393(6)$ \\
$\mathrm{C} 2-\mathrm{C} 3$ & $1.398(7)$ & $\mathrm{C} 3-\mathrm{C} 4$ & $1.375(7)$ & $\mathrm{C} 2-\mathrm{C} 7$ & $1.492(7)$ \\
$\mathrm{C} 4-\mathrm{C} 5$ & $1.375(7)$ & $\mathrm{C} 6-\mathrm{C} 8$ & $1.512(6)$ & $\mathrm{C} 5-\mathrm{C} 6$ & $1.382(6)$ \\
$\mathrm{C} 2-\mathrm{C} 1-\mathrm{C} 6$ & $123.7(4)$ & $\mathrm{C} 2-\mathrm{C} 1-\mathrm{N} 1$ & $118.2(4)$ & $\mathrm{C} 1-\mathrm{C} 2-\mathrm{C} 3$ & $116.1(4)$ \\
$\mathrm{C} 4-\mathrm{C} 3-\mathrm{C} 2$ & $121.7(4)$ & $\mathrm{C} 1-\mathrm{C} 2-\mathrm{C} 7$ & $122.6(4)$ & $\mathrm{C} 3-\mathrm{C} 2-\mathrm{C} 7$ & $121.2(4)$ \\
$\mathrm{C} 3-\mathrm{C} 4-\mathrm{C} 5$ & $119.8(4)$ & $\mathrm{C} 6-\mathrm{C} 5-\mathrm{C} 4$ & $121.7(5)$ & $\mathrm{C} 6-\mathrm{C} 1-\mathrm{N} 1$ & $118.0(4)$ \\
$\mathrm{C} 1-\mathrm{C} 6-\mathrm{C} 5$ & $116.9(4)$ & $\mathrm{C} 1-\mathrm{C} 6-\mathrm{C} 8$ & $122.2(4)$ & $\mathrm{C} 5-\mathrm{C} 6-\mathrm{C} 8$ & $120.8(4)$ \\
\hline
\end{tabular}

2,6- $\left(\mathrm{CH}_{3}\right)_{2}-\mathrm{C}_{6} \mathrm{H}_{3} \mathrm{~N}(2) \mathrm{H}_{3}$

\begin{tabular}{cccccc}
$\mathrm{N} 2-\mathrm{C} 9$ & $1.482(6)$ & $\mathrm{C} 9-\mathrm{C} 10$ & $1.388(6)$ & $\mathrm{C} 9-\mathrm{C} 14$ & \\
$\mathrm{C} 10-\mathrm{C} 11$ & $1.398(7)$ & $\mathrm{C} 11-\mathrm{C} 12$ & $1.377(7)$ & $\mathrm{C} 10-\mathrm{C} 15$ & $1.503(6)$ \\
$\mathrm{C} 12-\mathrm{C} 13$ & $1.369(8)$ & $\mathrm{C} 14-\mathrm{C} 16$ & $1.504(7)$ & $\mathrm{C} 13-\mathrm{C} 14$ & $1.380(7)$ \\
$\mathrm{C} 9-\mathrm{C} 10-\mathrm{C} 11$ & $116.4(4)$ & $\mathrm{C} 10-\mathrm{C} 9-\mathrm{N} 2$ & $117.8(4)$ & $\mathrm{C} 9-\mathrm{C} 14-\mathrm{C} 16$ & $122.3(4)$ \\
$\mathrm{C} 10-\mathrm{C} 11-\mathrm{C} 12$ & $121.0(5)$ & $\mathrm{C} 11-\mathrm{C} 12-\mathrm{C} 13$ & $119.9(5)$ & $\mathrm{C} 12-\mathrm{C} 13-\mathrm{C} 14$ & $122.2(5)$ \\
$\mathrm{C} 13-\mathrm{C} 14-\mathrm{C} 16$ & $121.4(5)$ & $\mathrm{C} 13-\mathrm{C} 14-\mathrm{C} 9$ & $116.3(5)$ & $\mathrm{C} 14-\mathrm{C} 9-\mathrm{N} 2$ & $118.0(4)$ \\
$\mathrm{C} 10-\mathrm{C} 9-\mathrm{C} 14$ & $124.2(4)$ & $\mathrm{C} 9-\mathrm{C} 10-\mathrm{C} 15$ & $123.1(4)$ & $\mathrm{C} 11-\mathrm{C} 10-\mathrm{C} 15$ & $120.5(4)$ \\
\hline
\end{tabular}

As expected, in the $\mathrm{ZnCl}_{4}{ }^{2-}$ anion, the $\mathrm{Zn}$ atom has a tetrahedral coordination surrounded by four $\mathrm{Cl}$ atoms. In the $\left[\mathrm{ZnCl}_{4}\right]$ tetrahedra, the mean values of $\mathrm{Zn}-\mathrm{Cl}$ lengths and $\mathrm{Cl}-\mathrm{Zn}-\mathrm{Cl}$ angles are $2.267 \AA$ and $109.5^{\circ}$, respectively, which are in agreement with those found in anilinium tetrachlorozincate ${ }^{19-21}$. The slightly deviation from the perfect tetrahedron around $\mathrm{Z}$ (II) can be explained by the involving of the chlorine ions in the hydrogen bonding. However, the $\mathrm{Zn}-\mathrm{Cl}$ bond lengths do not differ appreciably from the shortest and longest bond lengths of 2.245(1) and 2.289(1) $\AA$ associated to $\mathrm{Zn}-\mathrm{Cl1}$ and $\mathrm{Zn}-\mathrm{Cl} 3$, respectively. In addition, the $\mathrm{Cl}-\mathrm{Zn}-\mathrm{Cl}$ bond angles are also comparable, varying between 105.15(5) and $114.71(6)^{\circ}$. All these data indicate a slight deviation from perfect tetrahedral environment 
around the zinc cation, according to literature results ${ }^{22}$ and in comparaison to the terachlorocuprate salt ${ }^{23}$. Indeed, in this compound, the $\mathrm{Cu}-\mathrm{Cl}$ bond leghts and $\mathrm{Cl}-\mathrm{Cu}-\mathrm{Cl}$ bond angles vary from $2.216(7)$ to $2.283(6) \AA$ and from $94.75(2)$ to $138.95\left(3^{\circ}\right)$, respectively, indicating a large deviation from perfect tetrahedral environment around $\mathrm{Cu}(\mathrm{II})$. An examination of the organic moiety geometrical features shows that, the carbon atoms building the two phenyl rings of the title compound have a good coplanarity and they form a conjugated planes with average deviation of 0.025 and $0.037 \AA$, and they form between them a dihedral angle of $7.32^{\circ}$. The two crystallography independent 2,6-xilidinium cations involved in this crystal packing, exhibit C-C and $\mathrm{C}-\mathrm{N}$ distances and $\mathrm{C}-\mathrm{C}-\mathrm{C}$ and $\mathrm{C}-\mathrm{C}-\mathrm{N}$ angles in the range usually found for this molecule ${ }^{24-25}$.

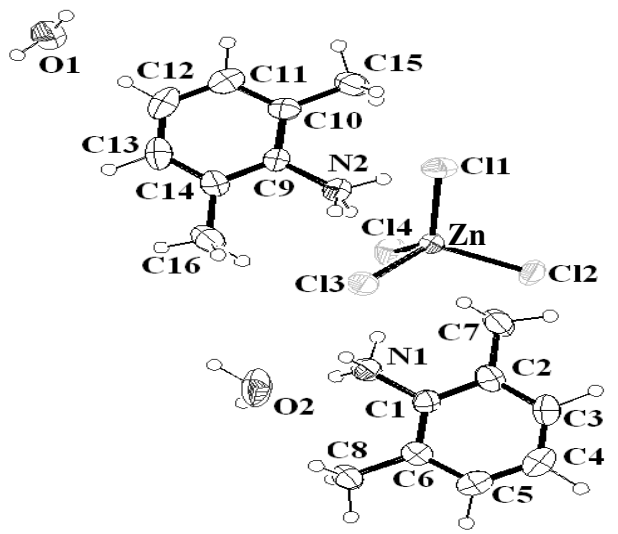

Figure 1. ORTEP representation of the molecular configuration of [2,6- $\left(\mathrm{CH}_{3}\right)_{2}$ $\left.\mathrm{C}_{6} \mathrm{H}_{3} \mathrm{NH}_{3}\right]_{2} \mathrm{ZnCl}_{4} \cdot 2 \mathrm{H}_{2} \mathrm{O}$, with atom numbering scheme and thermal ellipsoids at $40 \%$ of probability.

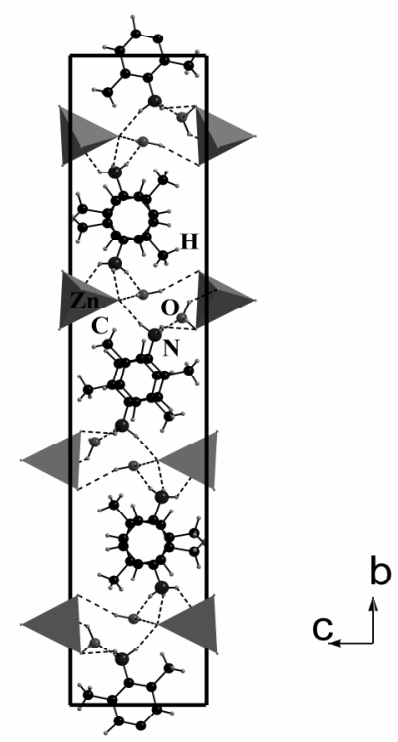

Figure 2. Projection of the $\left[2,6-\left(\mathrm{CH}_{3}\right)_{2}-\mathrm{C}_{6} \mathrm{H}_{3} \mathrm{NH}_{3}\right]_{2} \mathrm{ZnCl}_{4} \cdot 2 \mathrm{H}_{2} \mathrm{O}$ structure in the plane (b, c). $\mathrm{ZnCl}_{4}$ is given in tetrahedral representation. Other atoms are indicated by their symbols. Hydrogen bonds are denoted by dotted lines. 


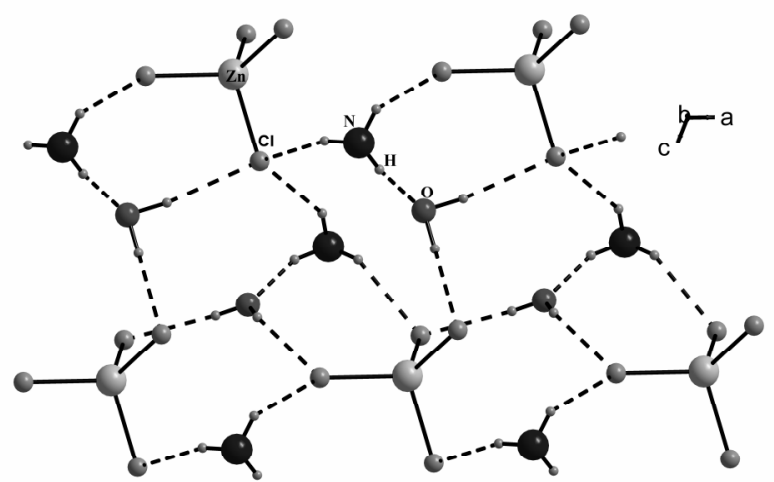

Figure 3. Projection of a layer, viewed down the b direction, in the structure of $\left[2,6-\left(\mathrm{CH}_{3}\right)_{2}\right.$ $\left.\mathrm{C}_{6} \mathrm{H}_{3} \mathrm{NH}_{3}\right]_{2} \mathrm{ZnCl}_{4} \cdot 2 \mathrm{H}_{2} \mathrm{O}$.

Table 4. Hydrogen-bond scheme in $\left[2,6-\left(\mathrm{CH}_{3}\right)_{2}-\mathrm{C}_{6} \mathrm{H}_{3} \mathrm{NH}_{3}\right]_{2} \mathrm{ZnCl}_{4} \cdot 2 \mathrm{H}_{2} \mathrm{O}$.

\begin{tabular}{ccccc}
\hline $\mathrm{D}-\mathrm{H} \ldots \mathrm{A}$ & $\mathrm{D}-\mathrm{H}(\AA)$ & $\mathrm{H} \ldots \mathrm{A}(\AA)$ & $\mathrm{D} \ldots \mathrm{A}(\AA)$ & $\mathrm{D}-\mathrm{H} \ldots \mathrm{A}\left({ }^{\circ}\right)$ \\
\hline $\mathrm{O}(1)-\mathrm{H}(1) \ldots \mathrm{Cl} 3$ & 1.04 & 2.58 & $3.619(4)$ & 170.6 \\
$\mathrm{O}(1)-\mathrm{H}(2) \ldots \mathrm{Cl} 1$ & 1.04 & 2.52 & $3.529(4)$ & 163.7 \\
$\mathrm{O}(2)-\mathrm{H}(3) \ldots \mathrm{Cl} 4$ & 1.09 & 2.35 & $3.203(5)$ & 133.4 \\
$\mathrm{O}(2)-\mathrm{H}(4) \ldots \mathrm{Cl} 2$ & 0.87 & 2.42 & $3.286(4)$ & 174.7 \\
$\mathrm{~N}(1)-\mathrm{H}(5) \ldots \mathrm{Cl} 3$ & 1.00 & 2.46 & $3.347(4)$ & 146.9 \\
$\mathrm{~N}(1)-\mathrm{H}(6) \ldots \mathrm{Cl} 2$ & 0.96 & 2.46 & $3.261(4)$ & 140.3 \\
$\mathrm{~N}(1)-\mathrm{H}(7) \ldots \mathrm{O} 2$ & 0.96 & 1.83 & $2.732(5)$ & 157.1 \\
$\mathrm{~N}(2)-\mathrm{H}(8) \ldots \mathrm{Cl} 4$ & 0.95 & 2.48 & $3.213(4)$ & 134.4 \\
$\mathrm{~N}(2)-\mathrm{H}(9) \ldots \mathrm{Cl} 3$ & 0.95 & 2.43 & $3.312(4)$ & 153.8 \\
$\mathrm{~N}(2)-\mathrm{H}(10) \ldots \mathrm{O} 1$ & 0.85 & 1.97 & $2.899(6)$ & 165.9 \\
\hline
\end{tabular}

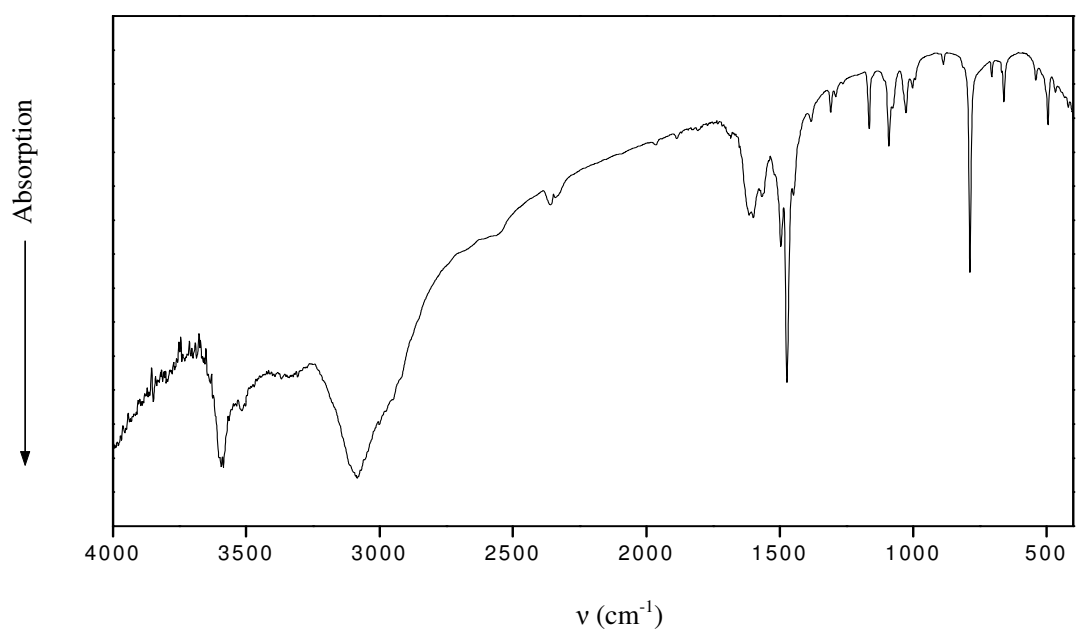

Figure 4. IR spectrum of $\left[2,6-\left(\mathrm{CH}_{3}\right)_{2}-\mathrm{C}_{6} \mathrm{H}_{3} \mathrm{NH}_{3}\right]_{2} \mathrm{ZnCl}_{4} \cdot 2 \mathrm{H}_{2} \mathrm{O}$ in $\mathrm{KBr}$ pellet. 


\section{IR spectroscopy investigations}

The IR spectrum of crystalline $\left[2,6-\left(\mathrm{CH}_{3}\right)_{2}-\mathrm{C}_{6} \mathrm{H}_{3} \mathrm{NH}_{3}\right]_{2} \mathrm{ZnCl}_{4} \cdot 2 \mathrm{H}_{2} \mathrm{O}$ is shown in Figure 4. To assign the IR peaks to vibrational modes, we have used the modes and frequencies observed in similar compounds ${ }^{26-27}$

- The high-frequency region broad bands, between $3600-2300 \mathrm{~cm}^{-1}$, are attributed to the stretching vibrations of organic and hydroxyl groups $v(\mathrm{C}-\mathrm{H}), \mathrm{v}(\mathrm{N}-\mathrm{H})$ and $\mathrm{v}(\mathrm{O}-\mathrm{H})$ of $\mathrm{H}_{2} \mathrm{O}$ molecules.

- The vibration bands between 1650 and $1200 \mathrm{~cm}^{-1}$ are assigned to bending vibrations of $\delta\left(\mathrm{NH}_{2}\right), \delta\left(\mathrm{CH}_{3}\right), \delta(\mathrm{O}-\mathrm{H}), \delta(\mathrm{C}-\mathrm{C})$, and valence vibrations $v(\mathrm{C}=\mathrm{C})$ and $v(\mathrm{C}=\mathrm{N})$.

- The bands in the $1000-700 \mathrm{~cm}^{-1}$ range can be attributed to bending modes $\delta\left(\mathrm{C}_{\text {aryl }}-\mathrm{H}\right)$ and $\delta\left(\mathrm{C}_{\text {aryl }}-\mathrm{C}_{\text {aryl }}\right)$ and $\delta\left(\mathrm{C}_{\text {aryl }}-\mathrm{N}_{\text {aryl }}\right)$.

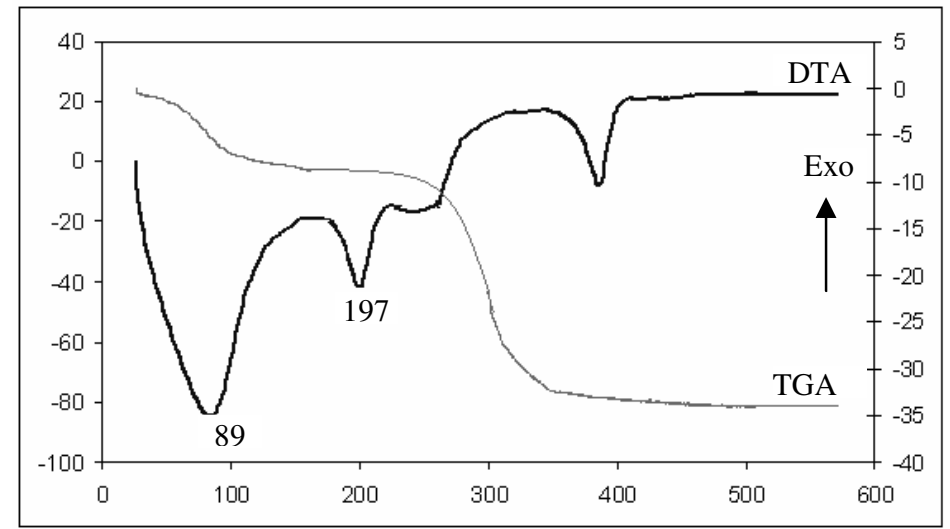

Figure 5. Thermal analysis curves (DTA and TG) under argon of [2,6- $\left(\mathrm{CH}_{3}\right)_{2}$ $\left.\mathrm{C}_{6} \mathrm{H}_{3} \mathrm{NH}_{3}\right]_{2} \mathrm{ZnCl}_{4} \cdot 2 \mathrm{H}_{2} \mathrm{O}$.

\section{Thermal analysis}

Curves corresponding to DTA and TGA analysis are reported in Figure 5. The DTA curve shows a succession of endothermic peaks. The first one $\left(89^{\circ} \mathrm{C}\right)$ corresponds to an elimination of the two crystallization water molecules, well confirmed by the weight loss observed on TGA curve (\% water experimental 7.30, calculated 7.38). After this dehydratation, the anhydrous compound melts towards $197{ }^{\circ} \mathrm{C}$, confirmed by a separate melting point determination of the title complex. By heating further, the important weight loss observed in the large temperature range, $250-500{ }^{\circ} \mathrm{C}$, corresponds to a decomposition of the obtained phase.

\section{Conclusion}

Good quality single crystals of 2,6-xylidinium tetrachlorozincate were grown by slow evaporation technique at room temperature. The structure of the title material is stabilized by different types of interactions and particularly an interesting $\mathrm{H}$-bond network. When heated, this complex loses the crystallisation water molecules and continues to decompose in a large temperature range.

\section{References}

1. Meyer G and Nockeman P, J Solid State Chem., 2001, 162, 254.

2. Qin J, Dai C, liu D, Chen C, Wu B, Yang C and Zhan C, Coord Chem Rev., 1999, 188, 23. 
3. Gaiser U, Wikket R D, Lindbeck M and Ertherson E, J Am Chem Soc., 1986, 108, 1173.

4. Lacroix P G, Chem Mater., 2001, 13, 3495.

5. Chestnut D J, Kusnetzow A, Brige R and Zubeita R J, Inorg Chem., 1999, 38, 2663.

6. Lacroix P G, Clement R, Nakatani K, Delaire J A, Zyss J and Ledoux I, Science, 1994, 263, 658.

7. Lu J Y, Cabrera B, Wang R J and Li J, Inorg Chem., 1999, 38, 4608.

8. Hammoud R P , Cavaluzzi M, Haushalter R C and Zubeita J A, Inorg Chem. 1999, 38, 1288.

9. Lehn J M, Angew Chem Int Ed Engl. 1990, 29, 1304.

10. Baxter PNW, Lehn J M, Kneisel B O and Fenske D, Angew Chem Int Ed Engl., 1997, 36, 1978.

11. Braga D, Grepioni F and Desiraju G R, Chem Rev., 1998, 98, 1375.

12. Hunter CA, Chem Soc Rev., 1994, 23, 101.

13. Puddephatt R J, Chem Commun., 1998, 1055.

14. Altomare A, Cascarano M, Giacovazzo C and Guzgliardi, J Appl Cryst., 1993, 26, 343.

15. TeXsan for Windows version 1.03, Molecular Structure Corporation, Single Crystal Structure Analysis Software, Version 1.03, MSC, 3200 Research Forest Drive, The Woodlands, TX, USA, 1997.

16. Brandenburg K Diamond Version 2.0 Impact GbR Bonn., Germany, 1998.

17. Johnson CK ORTEP. Report-3794, Oak Ridge National Laboratory: Oak Ridge TN, 1965.

18. Janiak J, J Chem Soc., Dalton Trans., 2000, 3885.

19. Zhi-Min J, Nan S, Ya L, Mao H and Liang S, Acta Cryst., 2005, C61, m43.

20. Bringley J F and Rajeswaran M, Acta Cryst., 2006, E62, m1304.

21. Ning G, Jianglong Y, Yuan C, Shijun L and Zhiyoung F, Acta Cryst. 2007, E63, m2571.

22. Ben Gharbia I, Kefi R and Ben Nasr C, Anal Sci.: X-Ray Struct Anal Online, 2007, 23, x243.

23. Bhattacharya R, Ghanda S, Bocelli G, Cantoni A and Ghosh A, J Chem Crystallo., 2004, 34, 393.

24. Mrad ML, Ben Nasr C and Rzaigui M Anal Sci.: X-Ray Struct Anal Online, 2006, 22, x227.

25. Abid S, Hemissi H and Rzaigui M, Acta Cryst., 2007, E63, o3117.

26. Soussi S, Smirani W, Ben Nasr C and Rzaigui M, Phosphorus Sulfur and Silicon, 2007, 182, 2731.

27. Bhattacharya R, Ray M S, Dey R, Righi L, Bocelli G and Ghosh A, Polyhedron, 2002, 21, 2561. 


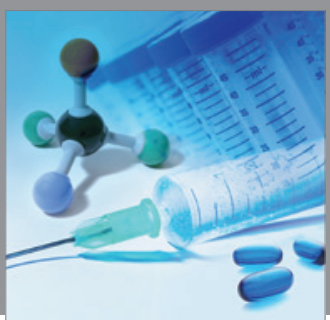

International Journal of

Medicinal Chemistry

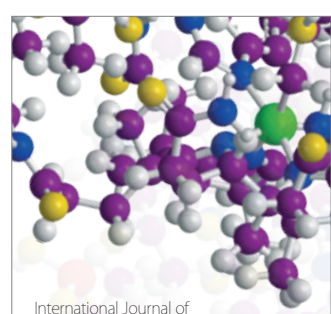

Carbohydrate Chemistry

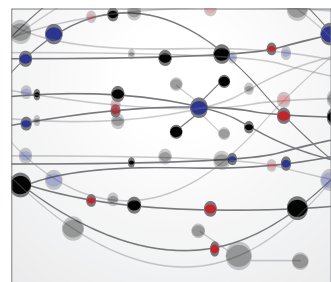

The Scientific World Journal
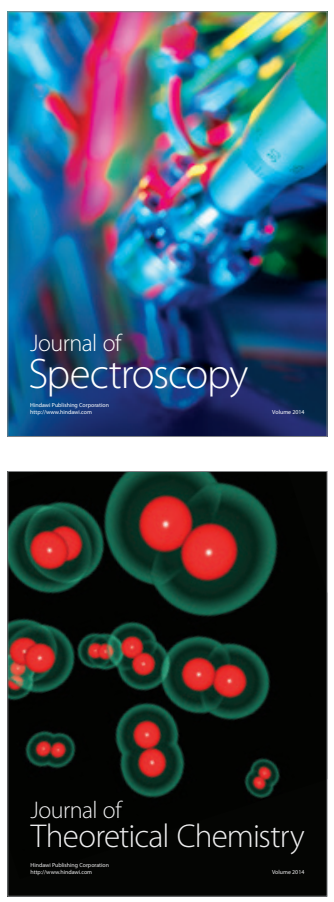
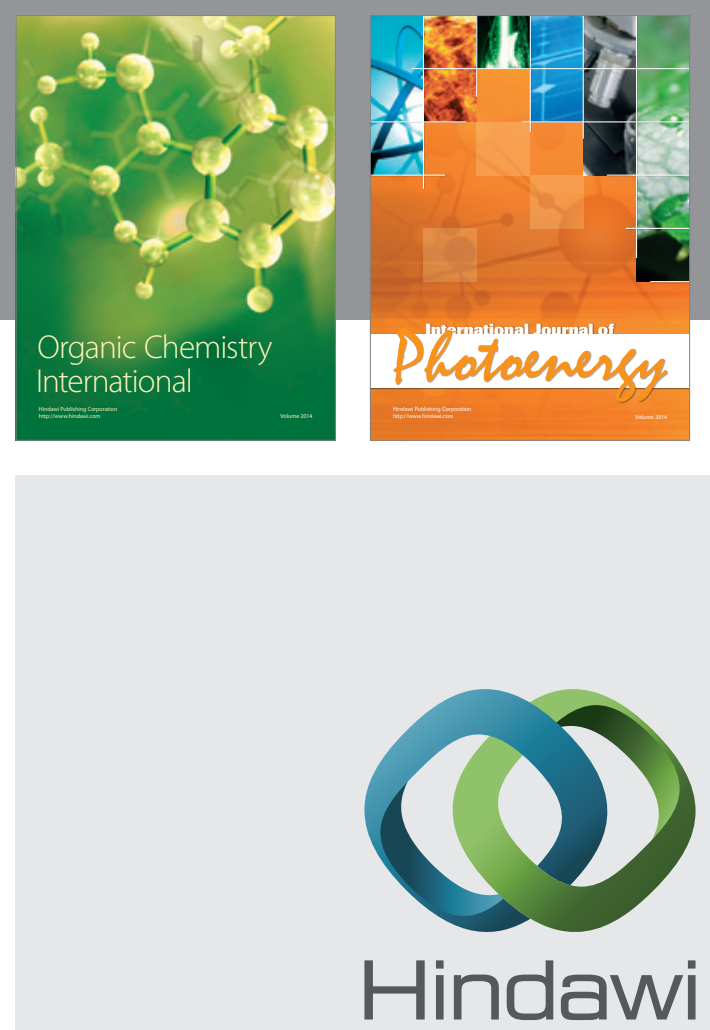

Submit your manuscripts at

http://www.hindawi.com
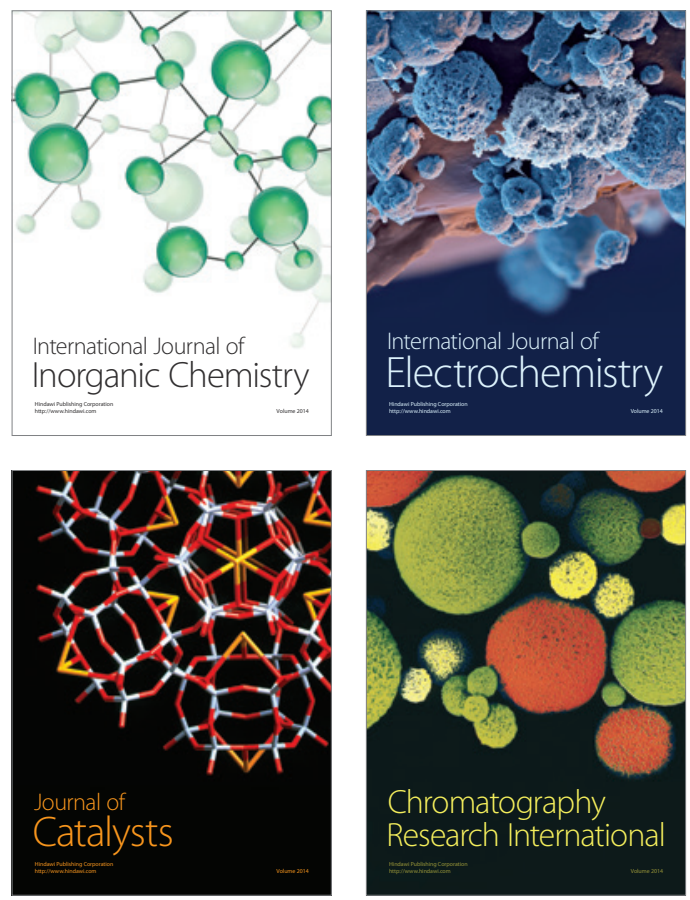
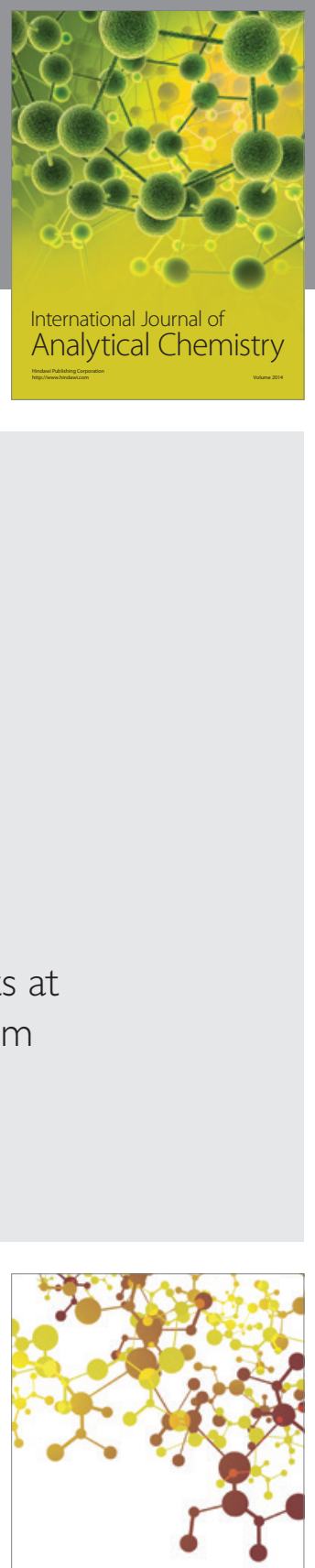

Journal of

Applied Chemistry
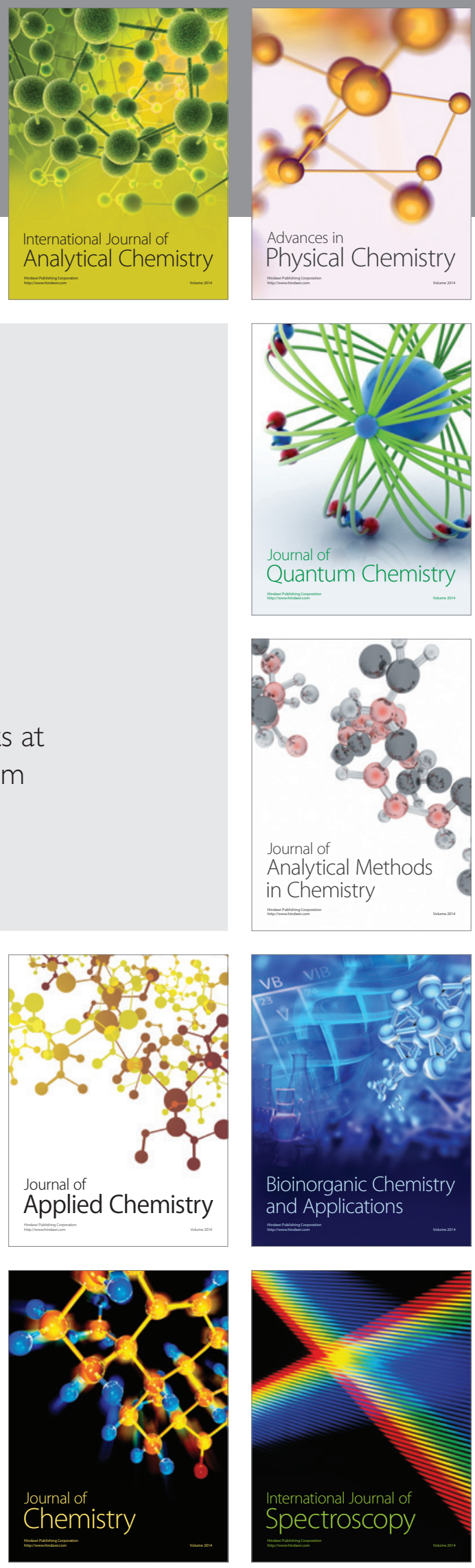